\title{
Tanggung Gugat Pengangkut Terhadap Keterlambatan Pengiriman Barang pada Angkutan Transportasi Laut
}

\author{
Carrier Responsibility Against Delay in Delivery of Goods in Sea \\ Transportation
}

\author{
Al Asgaf Kamaluddin \\ Pascasarjana Universitas Halu Oleo \\ E-mail:aga_asgaf@ymail.com \\ Guswan Hakim \\ Pascasarjana Universitas Halu Oleo \\ E-mail: ghakim125@gmail.com \\ Jabalnur \\ Pascasarjana Universitas Halu Oleo \\ E-mail: jabalnur821@gmail.com \\ Deity Yuningsih \\ Pascasarjana Universitas Halu Oleo \\ E-mail: deity.yuningsih@yahoo.com
}

\begin{abstract}
Whereas the Carrier Liability is based on Article 468 of the Criminal Code and the 1924 Brussels Convention in the event of a deviation due to avoiding a natural event that has never been taken into account, the Carrier must be exempted from Liability. The settlement of a dispute in the transportation of goods by sea has generally been regulated in a bill oflading as a conditioan of carriage as stated in the cassatoria clause. Because the regulations in the $B / L$ are made unilaterally, namely from the carrier only, so to protect the interests of the sender and receiver the shipping company refers to the highest law (paramount clause) which is used to resolve disputes with senders and recipients. For ocean shipping companies, the highest law refers to The Hague-Visby Rules 1924, The Hamburg Rules 1978, or USA cogsa 1936 in addition to the laws of the country of origin of the voyage and the country of origin of the goods. Meanwhile, the regulation on domestic shipping refers to Article 470 KUHD.PT. Buana Benua Shipping Service, Kolaka Branch, as an agent of Marfret Line has a Bill of Lading which adheres to the paramount clause of French law and adheres to local laws where goods originate in the event of a dispute.
\end{abstract}

Keyword: Transporter; Liability; Dispute Resolution

Abstrak: Bahwa Tanggung gugat pengangkut berdasarkan Pasal 468 KUHD dan Konvensi Brussel 1924 dalam hal terjadi deviasi karena menghindari suatu kejadian alam yang tidak pernah diperhitungkan maka Pengangkut harus dibebaskan dari Tanggung 
gugat. Penyelesaian suatu sengketa dalam pengangkutan barang melalui laut pada umumnya telah diatur dalam konosemen atau Bill of Lading sebagai persyaratan pengangkutan (condition of carriage) sebagaimana tercantum dalam cassatoria clause. Karena peraturan di dalam $B / L$ dibuat secara sepihak yaitu dari pihak carrier saja maka untuk melindungi kepentingan pengirim dan penerima perusahaan pelayaran menunjuk pada hukum yang tertinggi (paramount clause) yang digunakan untuk menyelesaikan sengketa dengan pengirim dan penerima. Untuk perusahaan pelayaran samudera menunjuk hukum yang tertinggi The Hague-Visby Rules 1924, The Hamburg Rules 1978, atau USA Cogsa 1936 di samping hukum dari Negara asal pelayaran tersebut dan Negara asal barang. Sedangkan pengaturan pada pelayaran nusantara mengacu pada Pasal 470 KUHD. PT. Buana Benua Shipping Service Cabang Kolaka, sebagai agen dari Marfret Line mempunyai Bill of Lading yang menganut paramount clause hukum Perancis dan menganut hukum setempat dimana barang berasal jika terjadi suatu sengketa.

Kata kunci: Pengangkut; Tanggung Gugat; Penyelesaian Sengketa

\section{PENDAHULUAN}

Pengangkutan memegang peranan penting, terutama dalam memperlancar arus barang maupun jasa dalam suatu alur perekonomian nasional bahkan global. Pengangkutan sebagai bagian dari sistem tataniaga, terutama berperan untuk memperlancar aliran suatu produk terutama dalam sistem perekonomian. Pengangkutan merupakan kegiatan untuk memindahkan penumpang dan atau barang dari satu tempat ke tempat lain dengan selamat. Pengangkutan adalah perjanjian timbal balik antara pengangkut dengan pengirim, di mana pengangkut mengikatkan diri untuk menyelenggarakan pengangkutan barang dan/atau orang dari suatu tempat ke tempat tujuan tertentu dengan selamat, sedangkan pengirim mengikatkan diri untuk membayar uang angkutan. ${ }^{1}$ Secara garis besarnya model pengangkutan dapat diklasifikasikan sebagai berikut: pengangkutan darat (pengangkutan melalui jalan (raya) dan kereta api), pengangkutan laut, dan pengangkutan Udara. Dari ketiga macam moda angkutan tersebut di atas, pengangkutan melalui laut mempunyai peran yang sangat besar dalam pengangkutan bagi Indonesia dan negara- negara lain di kawasan ASEAN. ${ }^{2}$

Dalam mengangkut barang, pengangkut dan pengirim barang terjadi suatu perjanjian yaitu perjanjian pengangkutan. Perjanjian pengangkutan ialah suatu perjanjian dimana satu pihak menyanggupi untuk dengan aman membawa orang atau barang dari satu ke lain tempat,

1 Purwosutjipto, Pengertian pokok Hukum Dagang Indonesia 3, Hukum Pengangkutan, Jakarta: Djambatan, 1991, hlm. 2. Dalam Muhammad Furqoni Ramadhan dan Muhammad Yasir, "Tanggung Jawab PT. Lintas Kumala Abadi dalam Kegiatan Pengangkutan Laut; Analisis Putusan Pengadilan Negeri Jakarta Barat No.642/PDT.G/2011/PN JKT.BAR”, Journal of Legal Research. Vol. 1 No. 1, 2019, hlm. 149.

2 Adnandaka Nurvigya, Alfian Nanung Pradana dan Rizki Nur Annisa, "Menelaah Waktu Terjadinya Resiko (Kehilangan/Kerusakan Barang) dalam Praktik Proses Pengangkutan Laut”, GEMA, THN XXVII, 50, Pebruari-Juli 2015, hlm. 1994. 
sedangkan pihak yang lainnya menyanggupi akan membayar ongkosnya. ${ }^{3}$ Dari definisi tersebut dapat diketahui bahwa perjanjian pengangkutan merupakan perjanjian timbal balik yaitu perjanjian timbal balik antara pengangkut dan pengirim barang dimana pihak pengangkut mengikatkan dirinya untuk menyelenggarakan pengangkutan barang atau orang ke tempat tujuan tertentu dan pihak pengirim barang atau penumpang mengikatkan dirinya pula untuk membayar ongkos angkutan. ${ }^{4}$ Selain perjanjian ini bersifat timbal balik juga bersifat konsensual yang berarti perjanjian ini terjadi apabila ada kata sepakat antara pengangkut dan pengirim atau dengan kata lain perjanjian dapat dilakukan secara lisan. Dari perjanjian pengangkutan ini menimbulkan tanggung jawab bagi masing-masing pengangkutan dan pengirim. Pengangkutan bertanggungjawab penuh terhadap keselamatan barang sedangkan pengiritn bertanggungjawab penuh pernbayaran ongkos angkutan. ${ }^{5}$

Keterlambatan penyampaian barang kepada pengirim ataupun penerima dapat disebabkan karena adanya penyimpangan (deviasi) terhadap jalur-jalur yang telah ditentukan/disepakati antara pihak pengangkut. Dalam praktiknya sehari-hari, penyimpangan jalur pelayaran (deviasi) terhadap jalur yang telah disepakati tampak dengan jelas pada salah satu peristiwa yang terjadi pada tanggal 15 Februari 2019 lalu yaitu pengangkut telah menyanggupi untuk mengangkut barang milik seorang pengusaha pengumpul Kakao di Kabupaten Kolaka Sulawesi Tenggara dengan jenis barang Kakao dari Kabupaten Kolaka dengan kapal Bulldrouck pelabuhan tujuan Port Klang Malaysia, dengan jadwal tiba di pelabuhan tujuan hari Minggu pukul 06.00 pagi. namun akibat terjadi penyimpangan jalur pelayaran (deviasi) mengakibatkan terjadi keterlambatan penyampaian barang kepada pembeli hingga 10 hari. Selain itu udara lembap di dalam kontainer/kapal menyebabkan biji Kakao sebanyak 1000 ton sebahagian berjamur menyebabkan pembeli di Malaysia membatalkan kontrak pembelian sehingga pengusaha kakao di Kabupaten Kolaka mengalami kerugian.

3 R. Subekti, Pokok-pokok Hukum Perdata, Jakarta: Intermasa, 2003, hlm. 221. Dalam Nurhasanah, Tinjauan Yuridis Peraturan Menteri Perhubungan Nomor 104 Tahun 2017 tentang Penyelenggaraan Angkutan Penyeberangan Terhadap Jasa Angkutan Penyeberangan (Studi di Penyeberangan Perahu Bermotor/Kapal Kempang Kecamatan Merbau Kabupaten Kepulauan Meranti). Skripsi, Riau: Universitas Islam Negeri Sultan Syarif Kasim Riau, 2019, hlm. 31.

4 H.M.N Purwasutjipto, Pengertian Pokok Hukum Dagang Indonesia, jilid II, Jakarta; Djambatan, 1999, hlm. 2

5 Edi As'Adi, Tanggung Jawab Pengangkut terhadap Kerugian Akibat Pelayaran Deviasi dalam Pengangkutan Barang melalui Laut di PT Arindo Jaya Mandiri Semarang. Skripsi, Semarang: Fakultas Hukum Unissula. 2004, hlm. 2. 
Keterlambatan ini memang sulit dibuktikan karena pengangkut biasanya sudah memperkirakan keterlambatan penyampaian barang. Dalam dunia pelayaran apabila terjadi keterlambatan untuk beberapa hari masih dapat ditoleransi oleh pengirim barang. Selain itu pengangkut untuk menghindari tanggung jawabnya dalam melakukan pengangkutan, biasanya pengangkut memberikan penjelasan kepada penerima barang bahwa tindakan yang dilakukannya force majeur. Force majeur adalah kejadian yang tidak dikehendaki atau di luar kekuasaan manusia. Apabila pengangkut tidak menghindari tanggung jawabnya maka pengangkut akan mengganti kerugian yang banyak antara lain keterlambatan dan kerusakan/kebusukan atas barang tersebut. Untuk itu penerima barang harus lebih cermat terhadap kerugian yang dilakukan oleh pengangkut. Berdasarkan hal tersebut, penulis tertarik untuk melakukan penelitian mengenai: "Tanggung Gugat Pengangkut Terhadap Keterlambatan Pengiriman Barang pada Angkutan Transportasi Laut"

Tulisan ini bertujuan untuk menjawab apakah Tanggung Gugat Pengangkut Terhadap Keterlambatan Pengiriman Barang akibat perubahan rute kapal Angkutan Transportasi Laut. dan apakah upaya hukum yang dilakukan oleh para pihak apabila terjadi kerusakan, kerugian, kehilangan akibat keterlambatan pengiriman barang.

\section{METODE PENELITIAN}

Jenis penelitian yang digunakan dalam penelitian ini adalah Penelitian normatif yaitu penelitian hukum yang meletakkan hukum sebagai sebuah bangunan sistem Norma. Sistem Norma yang dimaksud adalah mengenai asas-asas, Norma, kaidah dari peraturan perundang-undangan, putusan pengadilan, serta doktrin. Penelitian hukum normatif dilakukan untuk menghasilkan argumentasi, teori atau konsep baru sebagai gambaran dalam menyelesaikan masalah yang dihadapi. Tipe penelitian normatif ini dilakukan dengan Cara mengkaji berbagai teori hukum dan konsep hukum yakni konsep Pengangkutan, Dokumen-dokumen Angkutan Muatan Laut, Pengangkutan Laut, General Cargo Vessel dan Pengertian Barang; Penelitian ini menekankan Pada analisis tanggung jawab pengangkut Terhadap Keterlambatan Pengiriman Barang akibat perubahan rute kapal Angkutan Transportasi Laut. 
ANALISIS DAN PEMBAHASAN

Tanggung Gugat Pengangkut Terhadap Keterlambatan Pengiriman Barang Akibat Perubahan Rute Kapal Angkutan Transportasi Laut

Masalah tanggung gugat dalam pengangkutan barang melalui laut merupakan hal yang sangat penting karena menyangkut masalah kepada siapa dan mengapa tanggung gugat pelaksanaan penyelenggaraan pengangkutan harus dibebankan. Tanggung gugat pada hakikatnya terdiri dari 2 aspek yaitu tanggung jawab yang bersifat kewajiban yang harus dilaksanakan sebaikbaiknya (responsibility) dan tanggung jawab ganti-rugi (liability) yaitu kewajiban untuk memberikan ganti-rugi kepada pihak yang dirugikan. Pada perbuatan cedera janji, dalam rangka suatu perjanjian yang dipermasalahkan adalah dalam hal apa pengangkut dapat dipertanggung gugatkan, dan dalam hal apa ia tidak dapat dipertanggung gugatkan, sehingga masalah Tanggung gugat dalam pengangkutan laut terfokus pada masalah tanggung gugat pengangkut.

KUHD Pasal 468 ayat 2 menyatakan bahwa pengangkut diwajibkan mengganti segala kerugian, yang disebabkan karena barang tersebut seharusnya atau sebagian tidak dapat diserahkannya, atau karena terjadi kerusakan pada barang itu kecuali apabila dapat dibuktikan bahwa tidak diserahkannya atau kerusakan tadi, disebabkan oleh malapetaka yang selayaknya tidak dapat dicegah atau dihindarkannya, atau cacat dari barang tersebut atau oleh kesalahan dari yang mengirimkannya.

Ketentuan tersebut merupakan dasar bagi Tanggung gugat ganti-rugi, dimana pengangkut harus memberi ganti rugi kepada pihak yang dirugikan. Dasar Tanggung gugat ganti-rugi juga terdapat pada pasal 5 Hamburg Rules, yang mengatakan bahwa pengangkut bertanggung gugat ganti-rugi (liable) atas kerugian akibat hilang atau rusaknya barang, apabila peristiwa kehilangan, kerusakan, atau kelambatan tersebut terjadi pada waktu barang berada dalam penguasaan pengangkut. Asas Tanggung gugat ganti rugi yang dianut pada hakikatnya adalah bahwa Tanggung gugat ganti rugi timbul jika terdapat unsur kesalahan yang menimbulkan tuntutan ganti rugi.

Demikian pula dalam Konvensi Brussel 1924 yang lebih dikenal dengan Hague Rules secara lebih tegas menyebutkan bahwa pengangkutan barang meliputi periode sejak barang dimuat sampai waktu barang tersebut dibongkar dari kapal. Dalam praktik pelayaran periode tanggung jawab tersebut lazim disebut " from loading to unloading" atau "from tackle to tackle". Pengertian yang lazim dianut adalah periode tersebut mulai sejak barang dimasukkan ke dalam kapal (dengan alat muat) sampai barang tersebut dikeluarkan dari kapal (dengan alat bongkar). 
Tuntutan klaim atas kerusakan barang biasanya berkisar sekitar masalah apakah terjadinya peristiwa kehilangan atau kerusakan tersebut ketika barang berada di atas kapal atau di terminal, yaitu sebelum barang di muat atau setelah barang di bongkar. Walaupun pengangkut bertanggungjawab berdasarkan ketentuan dalam konosemen, namun apabila secara riil pengangkut melakukan kegiatan bongkar-muat atau penyimpanan, ia tidak dapat lepas dari Tanggung gugat perdata yang diatur dalam KUH Perdata dan PP No. 5/1964 dan peraturan yang menggantikannya PP No. 2/1969 menganggap kegiatan usaha pelayaran mencangkup kegiatan bongkar-muat dengan alasan perlunya kebulatan Tanggung gugat pengangkut. Sedangkan PP No. 17/1988 mengatur bahwa usaha bongkar-muat dilakukan oleh perusahaan yang berdiri sendiri. PP No17/1988 menetapkan bahwa kegiatan bongkar muat dapat dilakukan baik oleh perusahaan pelayaran maupun oleh perusahaan bongkar muat kapal.6

Pasal II Hague Rules menyatakan bahwa pengangkut wajib sebelum dan pada permulaan perjalanan melakukan dengan penuh kesungguhan (due diligence) hal-hal sebagai berikut; Membuat kapal layak-laut, Mengawaki, melengkapi dan membekali kapal sebagaimana seharusnya, Membuat ruangan-ruangan, kamar refrigrasi dan kamar pendingin dan bagianbagian lain kapal dimana barang dimuat, dalam keadaan baik dan aman untuk menerima, mengangkut dan menjaga keutuhan barang tersebut.

Selanjutnya ketentuan tersebut meneruskan, bahwa dengan memperhatikan berbagai pengecualian yang berlaku baginya, pengangkut wajib memuat, menagani, menyusun, mengangkut, menjaga dan membongkar barang-barang tersebut sebagaimana mestinya dan berhati-hati. Di dalam KUHD Buku II Bab V a tidak secara eksplisit mencantumkan kewajibankewajiban demikian itu. Hanya dari Pasal 468 ayat 2, Pasal 470 ayat 1, dan Pasal 470a ayat 1 secara penafsiran a contrario dapat disimpulkan bahwa pengangkut berkewajiban untuk melakukan hal-hal sebagai berikut; Menjaga keselamatan barang yang diangkut dengan baik, Memelihara perlengkapan kapal, melengkapi dan memakai kapal dengan baik. Jelaslah bahwa pada hakikatnya pengangkut mempunyai kewajiban-kewajiban untuk membuat kapal layak laut dan layak muat (Sea-Worthy and Cargo-Worthy)

Walaupun pengangkut dinyatakan mempunyai Tanggung gugat, namun adakalanya ia bebas dari tanggung jawab. Terutama dalam keadaan yang luar biasa yang berada di luar

6 Siti Aminah, Pelaksanaan Tanggung Jawab Para Pihak dalam Perjanjian Pengangkutan Barang Melalui Laut di PT. Barwil Unitor Ships Service Semarang, Tesis, Semarang: Program Studi Magister Kenotariatan Program Pascasarjana Universitas Diponegoro, 2007, hlm. 99, 
kekuasaannya yang menyebabkan terjadinya peristiwa yang tidak diinginkan itu, seyogyanya pengangkut memang sepantasnya bebas dari Tanggung gugat . Biasanya hal-hal tersebut meliputi peristiwa yang disebut "force majeur". Hal ini telah diterima sebagai prinsip umum. Namun force majeur pun dapat bersifat relatif andai kata dihubungkan dengan upaya maksimal dan wajar mengenai apa yang seharusnya dilakukan untuk mencegah terjadinya suatu peristiwa yang tidak di inginkan itu, Hal ini menyangkut penilaian pada kondisi dan fakta-fakta yang dihadapi.

Deviasi kapal MV. Lintas Mahakam yang bertolak dari pelabuhan Kolaka menuju pelabuhan Klang Malaysia dengan rute yang telah disepakati yaitu Pelabuhan Kolaka-Teluk Bone-Makassar-Surabaya-Tanjung Priok dan selanjutnya ke Selat Malaka pelabuhan Klang Malaysia menjadi rute Pelabuhan Kolaka-Teluk Bone-Makassar-Selat Makassar-BalikpapanTarakan-Laut Utara Kalimantan dan pelabuhan Klang Malaysia yang ditempuh selama 30 hari yang disebabkan oleh cuaca yang jelek, pengangkut harus di bebaskan dari tanggung jawab pengangkut untuk memberi ganti rugi.

\section{Upaya Hukum Pihak yang Dirugikan dalam Perjanjian Pengangkutan Melalui Laut}

Pengaturan hukum tentang penyelesaian sengketa adalah merupakan salah satu bentuk perlindungan hukum dalam upaya para pihak mempertemukan kepentingan sehingga didapatkan penyelesaian yang berkeadilan bagi para pihak dalam perjanjian pengangkutan melalui kapal laut. Terdapat dua jenis, upaya hukum dalam penyelesaian sengketa yaitu upaya hukum non-yudisial (di luar peradilan) dan upaya hukum yudisial (peradilan). Upaya hukum non-yudisial bersifat pencegahan sebelum pelanggaran terjadi (preventif) yang berupa tindakan- tindakan seperti peringatan, teguran, somasi, keberatan, dan pengaduan. Sedangkan upaya hukum yudisial bersifat represif/korektif artinya telah memasuki proses penegakan hukum (law enforcement), upaya ini dilakukan setelah pelanggaran terjadi dengan maksud untuk mengembalikan atau memulihkan keadaan. "Muara dari upaya hukum adalah agar hak yang dimiliki seseorang terhindar dari gangguan atau apabila hak tersebut telah dilanggar maka hak tersebut akan dapat dipulihkan kembali. Namun demikian, tidaklah dapat diartikan bahwa dengan adanya upaya hukum maka keadaan dapat dikembalikan sepenuhnya".7

\footnotetext{
7 Harjono, Konstitusi Sebagai Rumah Bangsa, Jakarta: Sekretaris Jenderal dan Kepaniteraan Mahkamah Konstitusi, 2008, hlm. 386, Dalam Tri Dian April Sesa, "Analisis Yuridis Kedudukan dan Perlindungan Hukum Pekerja Rumah Tangga (PRT) Dilihat dari Perspektif Peraturan Perundang-undangan Bidang Ketenagakerjaan", Jurnal Nestor Magister Hukum, Vol 1, No 1, 2016, hlm. 22.
} 
Dalam melaksanakan upaya hukum penyelesaian sengketa para pihak dalam perjanjian pengangkutan diprasyaratkan untuk menentukan hukum mana yang akan berlaku hal ini dapat merujuk kepada pilihan hukum kedua belah pihak serta yurisdiksi dan penegakkan hukum. Pilihan hukum dalam penyelesaian suatu sengketa dalam pengangkutan barang melalui laut pada umumnya telah diatur di dalam konosemen atau Bill of Lading sebagai suatu persyaratan pengangkutan. Hal-hal yang menyangkut pilihan hukum dan yurisdiksi ini menjadi klausul yang sangat penting. Pilihan hukum adalah hal mengenai hukum apa yang berlaku dalam melaksanakan perjanjian yang bersangkutan termasuk dalam penyelesaian sengketa. Sedangkan yurisdiksi pada hakikatnya mengenai masalah pilihan pengadilan mana yang dikehendaki untuk menyelesaikan sengketa. Termasuk pula adanya kemungkinan untuk menyelesaikan sengketa melalui arbitrase. ${ }^{8}$

\section{KESIMPULAN}

Bahwa tanggung gugat berdasarkan Pasal 468 KUHD dan Konvensi Brussel 1924 PT. Buana Benua Shipping Service Cabang Kolaka sebagai pengangkut berkewajiban menyelenggarakan pengangkutan dan menjaga keselamatan barang yang diangkut hingga diserahkan pada penerima barang di pelabuhan tujuan termasuk berupaya melayani trayek kapal yang telah disepakati untuk menghindari terlambatnya barang diserahkan kepada penerima sesuai kontrak jual beli antara penjual dan pembeli barang tersebut, namun dalam hal terjadi deviasi karena menghindari suatu kejadian alam yang tidak pernah diperhitungkan maka PT. Buana Benua Shipping Service Cabang Kolaka harus dibebaskan dari tanggung gugat. Penyelesaian suatu sengketa dalam pengangkutan barang melalui laut pada umumnya telah diatur dalam konosemen atau bill of lading sebagai persyaratan pengangkutan (condition of carriage) sebagaimana tercantum dalam cassatoria clause. Karena peraturan di dalam B/L dibuat secara sepihak yaitu dari pihak carrier saja maka untuk melindungi kepentingan pengirim dan penerima perusahaan pelayaran menunjuk pada hukum yang tertinggi (paramount clause) yang digunakan untuk menyelesaikan sengketa dengan pengirim dan penerima. Untuk perusahaan pelayaran samudera menunjuk hukum yang tertinggi The Hague-Visby Rules 1924, The Hamburg Rules 1978, atau USA cogsa 1936 di samping hukum dari Negara asal pelayaran tersebut dan Negara asal barang. Sedangkan pengaturan pada pelayaran nusantara mengacu

8 Riska Andita, Siti Mahmudah, dan Sartika Nanda Lestari, "Implementasi Asas Konsensual pada Perjanjian Pengangkutan Barang Melalui Laut dalam Kegiatan Ekspor Impor oleh PT DHL Global Forwarding Indonesia", Diponegoro Law Review, Volume 5, Nomor 2, 2016, hlm. 8. 
Pada Pasal 470 KUHD. PT. Buana Benua Shipping Service Cabang Kolaka, sebagai agen dari Marfret Line mempunyai bill of lading yang menganut paramount clause hukum Perancis dan menganut hukum setempat dimana barang berasal jika terjadi suatu sengketa.

\section{Daftar Pustaka}

\section{Buku}

Harjono, Konstitusi Sebagai Rumah Bangsa, Jakarta: Sekretaris Jenderal dan Kepaniteraan Mahkamah Konstitusi, 2008.

Purwasutjipto, H.M.N, Pengertian Pokok Hukum Dagang Indonesia, jilid II, Jakarta; Djambatan, 1999.

Purwosutjipto, Pengertian pokok Hukum Dagang Indonesia 3, Hukum Pengangkutan, Jakarta: Djambatan, 1991.

Subekti, R., Pokok-pokok Hukum Perdata, Jakarta: Intermasa, 2003.

\section{Jurnal dan Makalah}

Aminah, Siti, Pelaksanaan Tanggung Jawab Para Pihak dalam Perjanjian Pengangkutan Barang Melalui Laut di PT. Barwil Unitor Ships Service Semarang, Tesis, Semarang: Program Studi Magister Kenotariatan Program Pascasarjana Universitas Diponegoro, 2007.

Andita, Riska, Siti Mahmudah, dan Sartika Nanda Lestari, “Implementasi Asas Konsensual pada Perjanjian Pengangkutan Barang Melalui Laut dalam Kegiatan Ekspor Impor oleh PT DHL Global Forwarding Indonesia", Diponegoro Law Review, Volume 5, Nomor 2, 2016.

As'Adi, Edi, Tanggung Jawab Pengangkut terhadap Kerugian Akibat Pelayaran Deviasi dalam Pengangkutan Barang melalui Laut di PT Arindo Jaya Mandiri Semarang. Skripsi, Semarang: Fakultas Hukum Unissula, 2004.

Nurhasanah, Tinjauan Yuridis Peraturan Menteri Perhubungan Nomor 104 Tahun 2017 tentang Penyelenggaraan Angkutan Penyeberangan Terhadap Jasa Angkutan Penyeberangan (Studi di Penyeberangan Perahu Bermotor/Kapal Kempang Kecamatan Merbau Kabupaten Kepulauan Meranti). Skripsi, Riau: Universitas Islam Negeri Sultan Syarif Kasim Riau, 2019.

Nurvigya, Adnandaka, Alfian Nanung Pradana dan Rizki Nur Annisa, "Menelaah Waktu Terjadinya Resiko (Kehilangan/Kerusakan Barang) dalam Praktik Proses Pengangkutan Laut", GEMA, THN XXVII, 50, Pebruari-Juli 2015. 
Ramadhan, Muhammad Furqoni dan Muhammad Yasir, “Tanggung Jawab PT. Lintas Kumala Abadi dalam Kegiatan Pengangkutan Laut; Analisis Putusan Pengadilan Negeri Jakarta Barat No.642/PDT.G/2011/PNJKT.BAR”, Journal of Legal Research. Vol. 1 No. 1, 2019.

Sesa, Tri Dian April, “Analisis Yuridis Kedudukan dan Perlindungan Hukum Pekerja Rumah Tangga (PRT) Dilihat dari Perspektif Peraturan Perundang-undangan Bidang Ketenagakerjaan", Jurnal Nestor Magister Hukum, Vol 1, No 1, 2016. 